\title{
原発巣不明顎下リンパ節転移癌の検討
}

\author{
藤田靖・菊地正明 - 関川和男 - 高橋善男 \\ 川村 仁・林 進武・岡辺治男* ・山本 肇*
}

\section{Submandibular lymph node metastases of unknown primary site}

\author{
Yasushi Fujrta - Masaaki KrkuchI - Kazuo Sekikawa - Yoshio Takahashi \\ Hiroshi Kawamura - Susumu Hayashi - Haruo OKabe* - Hajime Yamamoto*
}

緒

言

䫟下リンパ節の腫脹をきたす疾患は炎症から腫瘍まで 多種多様で，悪性腫煌の転移の場合も，頭頸部領域の腫 瘍からだけでなく，胸部，腹部その他身体各部からもみ られる。

一般炕，悪性腫瘍の場合には，原発巣あるいはその隣 接眮器代伴ら症状がます現れ，それを主訴として来院す る場合が最す多いが，なかには，転移巣が原発巣に先行 して出現する場合もある．特に，頸部，靧下部に括いて は，わずかな腫脹でる自他覚的に捉えやすいために，同 部の尰脹を主訴として来院し，悪性腫瘍の転移と診断さ れることはしばしば経験する。しかし，そのはとんどは 原発栄の診断は比較的容易である。

ところが，諸種の検査によっても原発巣を発見し得な い場合もありこのことは古くからいわれているが，そ の報告は少ない。

最近，われわれは，顎下部の尰脹を主訴として来院

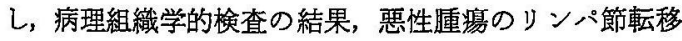
であったkるかかわらず，その原発巣を見い出し得なか った症例を 3 例経験したので，若干の考察を加占報告す る.

東北大学楼学部第 1 口腔外科学教室（主任：林 進武教授)

* 東北大学齿学部口腔病理学教室 (主任 : 山本 腎 教授）

First Department of Oral Surgery, School of Dentistry, Tohoku University (Chief: Prof. Susumu Hayashi)

* Department of Oral Pathology, School of Dentistry, Tohoku University (Chief: Prof. Hajime Yamamoto)

受付日：昭和56年 6 月 24 日
表 1 䫑下部の尰腿を主訴として来院した 患者の組織型と原発部位

\begin{tabular}{|c|c|c|c|c|c|}
\hline 原発部位 & 組織 & 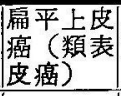 & 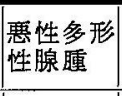 & $\begin{array}{l}\text { 未分化 } \\
\text { 腺癌 }\end{array}$ & 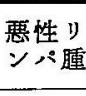 \\
\hline 頓 粘 & 膜 & 2 & & \multirow{4}{*}{1} & \multirow{5}{*}{3} \\
\hline 䫇 下 & 腺 & 1 & 1 & & \\
\hline 甲 状 & 腺 & & & & \\
\hline 䝷下リン & 節 & & & & \\
\hline 不 & 明 & 1 & 1 & 1 & \\
\hline
\end{tabular}

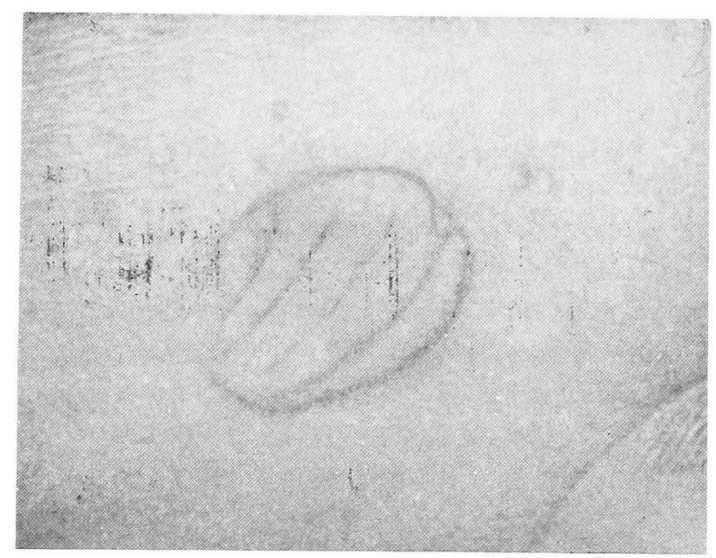

写真 1 症例 1 の病態写真 右側罰下部の尰場を示す。

\section{対象ならびに頻度}

昭和 51 年 1 月 1 日より昭和 55 年 12 月 31 日 での 5 年間 K，大学歯学部附属病院第 1 口腔外科を受診し，何 らかの処置をうけた覀性腫瘍（白血病は除く）患者は 148 名で, そのうち, 買下部の腫脹を主訴として来院し た思者は11名 (7.4\%)である. その組織型と原発部位と の関係は表 1 のごとくで，3名がいわゆる原発巣不明転 


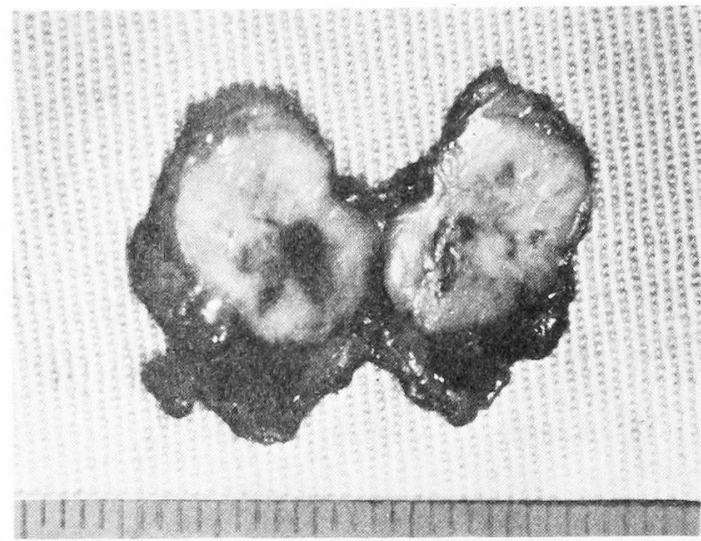

写真 2 症例 1 の摘出物の割面

移癌であった。これは悪性腫瘍患者の $2 \%$ に相当する，

症

例

症例 $1:$ 48歳 女.

初診：昭和51年 2 月日日.

主 訴：右側顎下部の腫脹。

家族歴：特記すべき事項なし。

既往歴：昭和50年 8 月曰日，罢検診にて胃のポリープ を指摘され，昭和51年 1 月口日，摘出手術をうけた。

現病歴：3 年ほど前, 右側䪶下部の腫脹に気ついた が，放監していたところ，昨年 7 月初旬頃より徐々に增 大してきた. 本年 1 月，胃ポリープの摘出手術後，当科 を釈介されて来院した。

初診時所見：体格中等度，栄盖状態良好で，全身状態 には特記すべき所見は認めなかった。

局所所見では，右側顎下部に鳵卵大の比較的境界明膫 な尰瘤を認めた，硬さは弾性硬で，可動性であった，压 痛は認めなかった（写真 1).

顎下腺管開口部からの吐液の排出は，左側に比へ，右 側はやや少ないが，特に異常はなく，一般蹦床検査成續 も正常であった。

臨床診断 : 右側顎下腺腫湯の疑い.

処置ならびに経過 : 右靧下腺摘出の予定で, 昭和51年

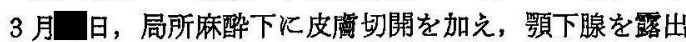
させたところ，外部より触知された腫瘤は買下腺とは別 で，顎下腺の前上方に位置したリンパ節であった，その リンパ節は一部罰下腺と㾉着していたが，比較的容易に 剥離されたので，顎下腺は摘出せず，リンバ節のみ摘出 した (写真 2).

病理組織学的検查の結果, 転移性恶性庫瘍之診断され たため，同年 4 月口日，全身麻酔の下に，右側上頸部の 廟清術を施行した。

術後, 内科，耳奥科など他科の検查でも巽常なく，経

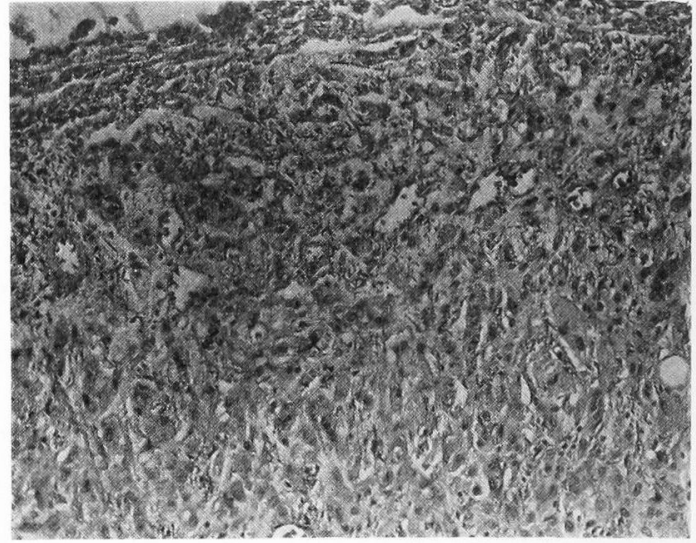

写真 3 定例 1 の組織像 $(\times 50)$

重性多形性腺腫のリンパ節転移

過は良好で， 5 年経過した現在も特に異常は認められな い.

病理組織学的所見：摘出したリンパ節はそその注とん どが酸好性の細胞質をるった紡鋟形の細胞からなる睡韵 組織で置きかかっている，なかに，多数の小衰胞が認め られ，一部に管腔の形成もみられる。間質は硝子様変化 をきたし，周围組織とは線維性の被膜で境されている部 分るあるが，浸潤性，破壊性の增殖像を示与部分もあ る(写真 3).

2 回目の右側上頸部晫清術の際摘出した顎下腺, 舌下

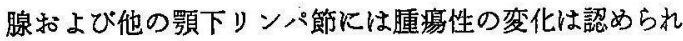
ない.

病理組織学的診断：悪性多形性腺連のリンパ節転移，

症例 2： 72歳 男.

初 診: 昭和 52 年 9 月回日.

主 訴 : 右側額下部の腫脹.

家族歴：特記すべき事項なし。

既往歴：34歳の時, 虫垂切除術をらけ，さらに60踻の 時，腎盂炎に罹患した，64歳の時には，緑内障の手術を らけた。

現病歴：前日，洗顔時に右顎下部の嗹脹に気づき，某 外科を受誩，当科を紹介されて来院した。

初診時所見：体格中等度，栄養状態良好で，全身状態 には特記すべき所見は認めなかった。

局所所見では，右側䫇下部に拇指頭大の境界明嘹な随 瘤を認めた，㾝瘤の硬さは弾性硬で，周囲組織とは可動 性であった、压痛はなかった。

左側䕘下部にも，小指頭大の可動性のりンパ節を 1 個 触知した。

顎下腺管開口部からの唾液排出は，両側とも，やや少 ないが，その他，一般臨床検査成䋶は正常であった。

臨床診断：多形性腺腫の疑い。

如置ならぴに経過：昭和 52 年 10 月口日，全身麻醉下 


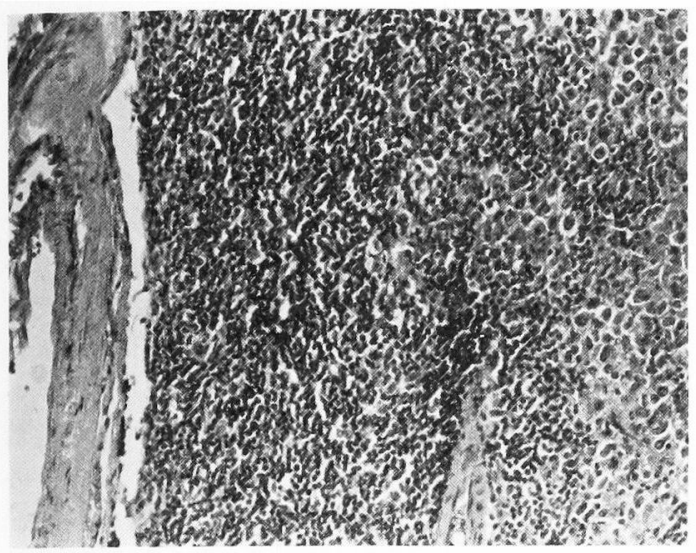

写真 4 症例 2 の組織像 $(\times 50)$

類表皮癌のリンパ節転移

に，口腔外より腫漡摘出術を施行したところ，腫瘍と思 われた腫瘤は実質性のリンバ節で, 割面は灰白色を呈し ていた，肉眼的所見より，悪性腫湯の転移が考えられた ため，さらに，右側上頸部の廊清術を施行し，顎下腺扣 よび所属リンパ節を一塊として摘出した。

術後経過悢良好で, 3 年 6 か月経過した現在, 局所的 Kる全身的にる，特異常は認められない

病理組織学的所見 - 多形性腺腫と考学られた摘出りン パ節のほとんどは血管の豊富な腫瘍組織で，クロマチン 飞富んだ大きな核をるつ腫瑒細胞からなっている，細胞 境界は明膫で，細胞間には重層扁平上皮にみられる細胞 間結合を認める。また，多数の核分裂像るみられる（写 真 4).

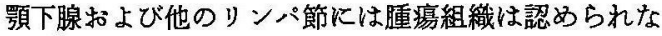
W.

病理組織学的診断：類表皮癌のリンパ節転移.

症例 3： 44 藏 男.

初診：昭和54年 8 月曰日.

主 訴：左側影下部の腫瘤。

家族捱：特記すべき事項なし。

既往歴：特記すべき事項なし。

現病歴：昭和54年 6 月初旬頃, 左側靧下部の腫瘤に気 づいたか，疼痛など特に症状もなかったため放置してい たところ，1か月後には，その腫瘤は増大し，数む 2 個 になったので某外科を受診した，リンパ節炎の診断のも とに化学療法をらけたが効果なく，庫瘤の数も 3 個にふ えたため当科を紹介され，来院した，

初診時所見：全身所見には特記すべき事項はない．

局所所見では，左側䫫下部にびまん性の尰脹を認め た，表面皮唐の色調は正常で，熱感はない，触診する と，〈るみ大 1 個，鳩畉大 1 個，大豆大 1 個，計 3 個の 腫瘾を触知した。 いずれも弾性硬で，周团組織 と瘾着 し，非可動性であったが，圧痛は認めなかった。

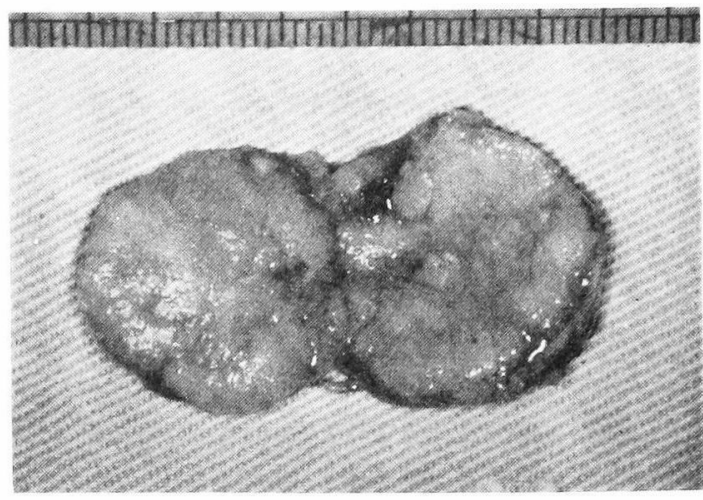

写真 5 症例 3 の摘出物の割面

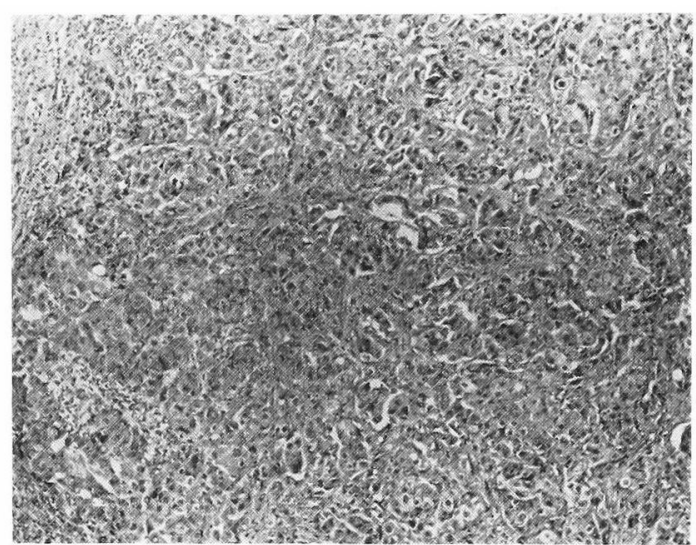

写真 6 症例 3 の組織像 $(\times 50)$

末分化腺癌のりンハ節転移

右側の罘下部にも，可動性のリンパ節が 2 個（腕豆大 1 個，小指頭大 1 個）触知された。

諸臨床検査では異常は認められなかった。

臨床診断：悪性リンパ腫の疑い.

処置ならびに経過：昭和 54 年 9 月 日, 全身麻酔下 そ，左側上頸部の澵清術を施行した，外部上り触知され た腫瘤は，一部で周囲組織と㴑着し，充実性で，割面は 灰白色を呈していた（写真 5).

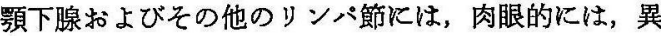
常は認められなかった。

術後，放射線㙩法（250 rad/日，20 回，総線量 5, 000 $\mathrm{rad}$ ) と化学療法 (CQ $1 \mathrm{mg}$ /日と PSK $3.0 \mathrm{~g}$ /日，30日 間，および FT-207 600mg/日とPSK $3.0 \mathrm{~g} /$ 日，I年間) を併用した。

術後, 内科, 耳鼻科, 泌尿器科など他科の検査をうけ たが異常なく，1年 8 か月経過した現在，経過は良好で ある。

病理組織学的所見：摘出物は，比較的大きな核とエオ ジン好性の顆粒を有する細胞の胞巣状増殖を示した腫瘍 組織からなるリンパ節で，その胞巣内には，一部，管腔 
の形成を認める．これらの細胞は異型性が強く，また， 核分裂像も多数みられる(写真 6).

特殊染色では, 細胞質は PAS (土), Alcian Blue (-) である。

顎下腺には異常所見は認められない。

病理組織学的診断：未分化腺癌のリンパ節転移.

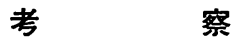

一般に, 原発巣不明癌といら場合，そのもつ意味はあ いまいで，報告者により多少の相違が認められるが，長 与1)は, 病理学者の立場から, 次の 5つのカテゴリーに 分類している.

A. 原発部位がわからなかった.

B．原発部位を確認できなかった。

C. 原発部位診断が間違っていた。

D. 癌を見落した。

E. 剖検であ原発部位が不明であった。

このうち, 真の意味の原発巣不明癌といらのは Eに属 するものだけであるが2)，実際に，臨床上経験するのは ほとんどAからDまでであり゙，われわれの経験した 3 例むAか Bに属するものである.

臨床的に原発巣をみつけ得ない, いわゆる原発巣不明 癌の頻度は比較的高く, 特に, 頸部リン八゚節転移の場 合は高く，悪性腫瘍患者の $1 \%$ から $4 \%$ といわれてい る $^{1,4,5)}$. われわれが，昭和51年 1 月 1 日から昭和55年 12 月31日までの 5 年間に扱かった悪性腫場患者は148名で， 原発巣不明癌の占める割合は $2 \%$ となり, 諸家の報告と 一致している.

原発巣をみつけ得ない理由として, Holmes \& Fouts4) や古江ら ${ }^{6)}$ は, 次のような事柄をあげている。

1. 原発巣が小さすぎて発見できない.

2. 原発巣が症状のでるのが遅い，診断のむずかしい 臓器の癌である。

3. 原発巣が silent である.

4. 原発巣がすでに破壊ないしはとりたされてしまっ た.

5. 原発巣が自然退縮してしまった。

しかるに, 䅡下リンパ節群においては，そのリンパ流 は, 前頭部, 顔面前方部, 下唇外側部，上下顎歯肉, 舌 深部および口腔底から集まり，次いで，上深および浅頸 リンパ節にそそぐ. したがって，悪性腫瘍で，顎下リン パ節に転移巣を認める場合，その原発巣はほとんど口腔 一顎一顔面領域の尰瘍で，しかも，すでに原発巣が確定 しているすのが大部分である ${ }^{2,3,7)}$. しかし, 他蔵器から の転移がないというのではなく，井口ら8にによれば，胃， 肺, 食道, 乳腺など上半身の臓器のみならず, 子宮癌か らも胃癌や乳癌と同じ程度の頻度で現れ，甲状腺癌や肺 癌においては，原発巣確定後に転移が現れたものと，転
移が初発したものとはほほ同数であるという，佐藤ら7) も，特に，原発巣が発見できない場合には，他臓器を徹 底的に探索しなければならないと忠告している。

さらに, 井ロら ${ }^{8)}$ は, 転移巣の組織像と原発臓器との 関連について検討しているが，最初に頸部転移巣が発見 され，後に，原発巣が判明した症例は 31 例で，そのう ち, 扁平上皮癌の 11 例中10例が咽頭癌， 1 例が食道癌で あった．腺癌は甲状腺癌 1 例, 肺癌 3 例, 胃癌 2 例であ ったといら。また，最後まで原発巣が判明しなかったも のでは, 転移巣が単純癌であったものが最も多く, 次い で, 腺癌, 扁平上皮癌であったという，われわれの症例 は, 扁平上皮癌が 1 例, 悪性多形性腺腫および腺癌が各 1 例で，いずれる，他科の協力を得て，その原発巣を探 索したが，ついに原発巣をみつけ得なかった，初発症状 出現以来, 2 年から 8 年と相当の年月が経過しているに もかかわらず，いまだ転移巣以外に症状が現れていな いといらことは，原発巣はすでに破壊ないしはとりださ れたか，自然退縮または治痹してしまったものと考えら れる。

原発巣不明癌の予後については, 非常に悪いものと, 案外良いものと両方の性格のものがあるといわれている

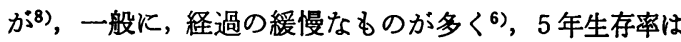
$20 \%$ 内外といわれている9). また， 2 年ないし 3 年以内 に原発巣が発見されなければ，すでに完治してしまい， 以後，決してみつからないともいわれている9． したが って，この意味からも，たと京発巣がみつからなくと も，転移巣に対してだけでも，根治をめざして治療すれ ば予後は決して悪くないるのと考劣られる．われわれの 症例も，現在のところ異常はなく，予後は非常に良い。

結語

昭和 51 年 1 月より昭和 55 年 12 月までの 5 年間に，臨床 的に原発巣をみつけ得なかった，いわゆる原発栄不明䫟 下リンパ節転移癌を 3 例経験したので, 若干の文献的考

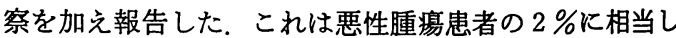
た.

なお，本論文の要旨は，第 5 回日本頭頸部腫富学会 （昭和56年 5 月，大阪）で発表した。

\section{引 用 文 献}

1）長与健夫：病理解剖を通してみた臨床診断上の 原発不明癌の検討. 癌の臨床 18：191 1972.

2) 竹田千里, 他 : 原発不明がん一頸部リンパ節転 移の検討. 癌の臨床 18: 1851972.

3）松村㤑二郎, 他 : 不顕性原発癌の頸部転移につ いて。耳舅と臨床 20：12 1974. 
4) Holmes, F.F. \& Fouts, T.L.: Metastatic cancer of unknown primary site. Cancer 26:816 1970.

5) 金田浩一, 他：原発不明癌の検討一放射線治癔 患者を中心に，癌の臨床 18：1641972.

6) 古江 尚, 他: 原発栄不明の癌. 癌の臨床 18 : 1591972.
7）佐藤文彦, 他：頸部腫瘤の臨床的観察一転移性 頚部腫瘤。瘦の臨床 18：197 1972.

8）井口潔，他：外科上りみた原発不明癌の検 討. 癌の臨床 18: 1711972.

9) 山際幹和, 他: 原発巣不明頸部転移癌. 癌の臨 床 23: 14251977. 